\title{
Organizational design of research results transfer offices: systematic revision of the literature ${ }^{1}$
}

Diseño organizacional de oficinas de transferencia de resultados de investigación: revisión sistemática de literatura

Recibido: 23 de agosto de 2013 Evaluado: 13 de septiembre 2013 Aceptado: 16 de octubre de 2013

\author{
Sandra Patricia Rojas-Berrio (Colombia) \\ sprojasb@gmail.com \\ Instituto Politécnico Nacional, México
}

\begin{abstract}
Andrés Felipe Ballesteros Ospina (Colombia)
afballesteros@poli.edu.co

Institución Universitaria Politécnico Grancolombiano

Eric Julián Rodríguez Martínez (Colombia)

erick_dc_03@hotmaill.com

Institución Universitaria Politécnico Grancolombiano
\end{abstract}

\begin{abstract}
This article presents a literature systematic review of the academic material published regarding the existing gaps that may create research problems in the Organizational Design and Research Results Transfer Office (OTRI for its acronym in Spanish) environment. This is based on the approach developed by Siegel, Waldman, \& Link, (2003). The main results are presented quantitatively from the findings obtained at SCOPUS, JStor, Academic Search Complete and EconLit.
\end{abstract}

Keywords: Organizational Design, Research Results Transfer Offices, Literature Systematic Review.

\section{Resumen}

Con el fin de descubrir los vacíos existentes que puedan llevar a construir problemáticas de investigación en el ámbito de diseño organizacional y oficinas de transferencia de resultados de investigación, este artículo presenta la revisión sistemática de literatura sobre lo publicado en el ámbito académico al respecto de las dos temáticas. Los principales resultados se exponen de manera cuantitativa a partir de los hallazgos en las búsquedas realizadas en Scopus, JStor, Academic Search Complete y Econlit.

Palabras clave: diseño organizacional, oficinas de transferencia de resultados de investigación, revisión sistemática de literatura.

1 "This work is the result of the 797 Agreement signed between the Colombian National Education Ministry and Institución Universitaria Politécnico Grancolombiano" 


\section{Introduction}

Organizational design is a challenge for companies within the global context (Vargas-Hernández, 2006). Rico et al (2004) justify their empirical research work regarding how important new forms of work organization are within the context of knowledge society. These authors took into account more specifically, the increase of the flexibility and participation of workers, which are topics that belong to organizational design.

Siegel, Waldman, \& Link, (2003) analyze the productivity of OTRIs by using the estimation of stochastic frontier as a tool and the Cobb-Douglas production function as an estimator. However, the authors indicate that there is a gap (page 28) in order to determine the way organizational tendencies affect productivity, and that this is the reason why their model changes.

On the other hand, Wijk, Jansen, \& Lyles, (2008)"mendeley" : \{ "manualFormatting": "Wijk, Jansen, \& Lyles, (2008 and Mayer, (2007) invite to analyze thoroughly the forms of knowledge transfer in order to fully understand its background and consequences. By using the metaanalysis methodology, the first model sets Performance and Innovation Capability as the main consequences and elucidates three key components as preceding events of the organizational knowledge transfer: Types of Knowledge, Organizational Dimension, and Generation of Networks.

Likewise, Tiffin \& Kunc, (2011) measure the roles universities play in development. Afterwards, they match those roles to what is defined as performance indicators: training (new extension courses), research, consulting, new firms, and facilitating linkages (among companies, state, and universities.) In addition, they suggest studying deeply these roles because micro-level problems may explain macrolevel problems.

Collecting the previous recommendations and the gaps found in the first model of this section, it is important to study organizational design as a premise, a micro-level problem, and a variable in the middle of knowledge transfer, especially, when Colombian universities are not wellprepared to face the challenge of taking part in ambitious projects of royalties for science, technology, and innovation. For all these reasons, this paper systematically revises all types of literature that can enlighten this topic of research and make us reflect about research results transfer and organizational design.

\section{Reference Framework}

Arocena \& Sutz, (2001) indicate that Higher Education Institutions are the main knowledge producers in Latin America. They set a series of scenarios in order for those institutions to interact between the generation of knowledge and their transformation. They basically outline two scenarios: one optimistic and the other one pessimistic. The following table summarizes the descriptions provided by the authors for each scenario: 
Table 1. Prospective of Knowledge Generation

\begin{tabular}{|l|l|}
\hline \multicolumn{1}{|c|}{ Optimistic Scenario } & \multicolumn{1}{c|}{ Pessimistic Scenario } \\
\hline - $\quad \begin{array}{l}\text { Productive actors trust in local R\&D } \\
\text { - } \begin{array}{l}\text { University-Business Alliances in order to face com- } \\
\text { plex strategic problems } \\
\text { - Successful cases of the previous items } \\
\text { - } \quad \begin{array}{l}\text { Structures to be adapted in universities focused on } \\
\text { business needs } \\
\text { - }\end{array}\end{array} \\
\text { Virtuous circle to solve local problems } \\
\text { Tensions that impede university growing }\end{array}$ \\
\hline
\end{tabular}

Source: Author's Compilation Based on Arocena \& Sutz, (2001)

Leaning towards the optimistic scenario, it is crucial to revise the knowledge management paradigm where Nonaka (2007) states that knowledge generation responds to the synergy and interaction between continuous and steady communication processes of what is tacit and explicit. Due to all this, it is possible for organizations to generate, transfer, and pass on knowledge between their contributors and stakeholders.

It is important to mention that tacit knowledge is the one that belongs to one or several individuals. It is implicit because it is not formal within the organization and corresponds to individual experiences or to the know-how of particular character. In contrast, explicit knowledge is formal and by definition, it should have evidence in the history of the organization. For this reason, and unlike tacit knowledge, it is easily transferable.

However, tacit and explicit knowledge coexist within a continuous synergy where the following interactions prevail:

- Systematization (Explicit to Explicit): Conversion of explicit knowledge into new formal-like knowledge.

- Appropriation (Explicit to Tacit): The know-how the organization acquires at the same time that formal knowledge is applied.
- Conceptualization (Tacit to Explicit): Formalization of explicit knowledge. - Dissemination (Tacit to Tacit): Transmitting to or assimilating informal knowledge from other individuals. (Ikujiro Nonaka, 2007)

Works like the one mentioned above or the one developed by Nonaka \& Takeuchi, (1999) revise rigorously the concept and processes of knowledge management and therefore transference in the interorganizational environment. It is possible to create a metaphor with these processes within the context of Higher Education Institutions because their mission is to appropriate, transfer, and produce knowledge not only to their students, but also to the society.

Different studies have analyzed the roles of universities as knowledge producers for urban development (Bugliarello, 1996; Perry \& Wiewel, 2005), technological and economic development (Cummings, Rosentraub, Domahidy, \& Coffin, 2005; Rodin, 2005), and development or social change (Ostrander, 2004).

Mayer, (2007) by focusing on the role of universities in economic development, says that the creation and increase of employment levels in innovative regions such as California's Silicon Valley, Boston's Route 128, Austin in Texas, and North 
Carolina's Research Triangle Park have brought Science, Technology, and Innovation public policy makers into trying to copy those models. Nevertheless, other regions such as Colorado Springs or Portland, OR, have been hubs of technological development with no universities nearby (Mayer, 2007, pp. 44-47).

In fact, the literature on the characterization of innovative regions talks about three models (Mayer, 2007, p. 34). The first one is characterized by the presence of research universities. The second model hosts research institutions that can or cannot be universities (Luger \& Goldstein, 1990; Saxenian, 1985), and the third one focuses on regions that do not have a research university (Mayer, 2007, p. 44).

To Tiffin \& Kunc, (2011) there are two ways in which universities can be part of the development of a region: generation and execution. According to the degree of autonomy and of interrelation of universities with their environment, it is possible for them to have roles such as Labor Force, Research -from their role applied to the industry or local problems (Coenen, Moodysson, Ryan, Asheim, \& Phillips, 2006; Fleet, 1993)-, Consultancy -helping the industry to solve immediate problems or to take advantage of opportunities (Arvanitis, Kubli, \& Woerter, 2008), Entrepreneurship -by favoring technological companies from the Spin-Off and Start-Up phenomena, (Zahra, Van de Velde, \& Larraneta, 2007; Luger \& Goldstein, 1990), and Cooperation Facilitator -among students, companies, and researchers (Cooke, 2002).

\section{Methodological strategy}

Due to the premises and guidelines highlighted by the previous authors, it is really important to measure the status of this topic along the last three decades. This is an essential topic for the construction of knowledge; therefore, it is of great interest to know the research and production status regarding OTRIs and OD (Organizational Design). Wijk, Jansen, \& Lyles, (2008)"mendeley" : \{ "manualFormatting” : "Wijk, Jansen, \& Lyles, (2008 and Mayer, (2007) invite to carefully examine these elements because of their relationship and cohesion to achieve transfer processes.

In order to measure this, we took as a reference point the last three decades and the scientific production -through their key words- regarding the main concepts revised in the introduction along with a synonym validated against three (3) experts: Organizational Design, Academic Research, and Transfer of Research Results.

These concepts were entered into the scientific databases SCOPUS, JStore, Academic Search, and EconLit. The search was filtered according to the already mentioned reference point. Table 2 indicates the search equations used. As a result, we obtained 4240 records for a 33 year period, between 1980 and 2013 . 
Table 2. Search Equations on Scientific Databases Used to Systematically Revise the Literature

\begin{tabular}{|l|l|r|}
\hline \multicolumn{1}{|c|}{ Tool/ Database } & \multicolumn{1}{|c|}{ Search Equation } & Number of Articles Found \\
\hline SCOPUS & $\begin{array}{l}\text { TITLE-ABS-KEY(("organizational de- } \\
\text { sign") AND ("academic research" OR } \\
\text { "research results transfer" OR (re- } \\
\text { search AND (group OR team)))) AND } \\
\text { PUBYEAR > 1979 }\end{array}$ & 144 \\
\hline JStore & $\begin{array}{l}\text { ("organizational design") AND ("aca- } \\
\text { demic research" OR "research results } \\
\text { transfer" OR (research AND (group } \\
\text { OR team))) }\end{array}$ & \\
\hline Academic Search Complete & $\begin{array}{l}\text { Organizational design AND acade- } \\
\text { mic research OR research results } \\
\text { transfer OR research AND group } \\
\text { team }\end{array}$ & \\
\hline EconLit & $\begin{array}{l}\text { organizational design") AND ("aca- } \\
\text { demic research" OR "research results } \\
\text { transfer" OR (research AND (group } \\
\text { OR team))) }\end{array}$ & 4142 \\
\hline Total & \multicolumn{2}{|l}{} \\
\hline
\end{tabular}

Source: Author's Compilation

Every Abstract and Full Text of the documents found was entered in the tool Mendeley. Duplicate data were deleted and the total number of documents was 3034 . These documents were analyzed as follows:

Revision of study field belonging if they met at least one of the following selection criteria:

1) The article is about Organizational Design (OD) within the entrepreneurial environment.

2) The article is about Organizational Design in Higher Education Institutions.

3) The article is about research results transfer within the entrepreneurial environment.

4) The article is about research results transfer structures within the Higher
Education environment (or in Higher Education Institutions) - (OTRI).

Each variable text was revised regarding: co-writing country or region of origin, approach, and methodology. Here, we present the findings.

\section{Findings}

When analyzing the time evolution of production regarding this research topic, Figure 1 was created. There, it is possible to observe several systematic behaviors of level, tendency, and seasonality by the display of an upward trend in the academic production of the last three (3) decades. 
Figure 1. Evolution of Production Documents Regarding Organizational

Design (OD) within the Entrepreneurial Environment and Higher Education Institutions; and Research Results Transfer Structures within the Entrepreneurial

Environment and Higher Education Institutions from 1980 to 2013

120

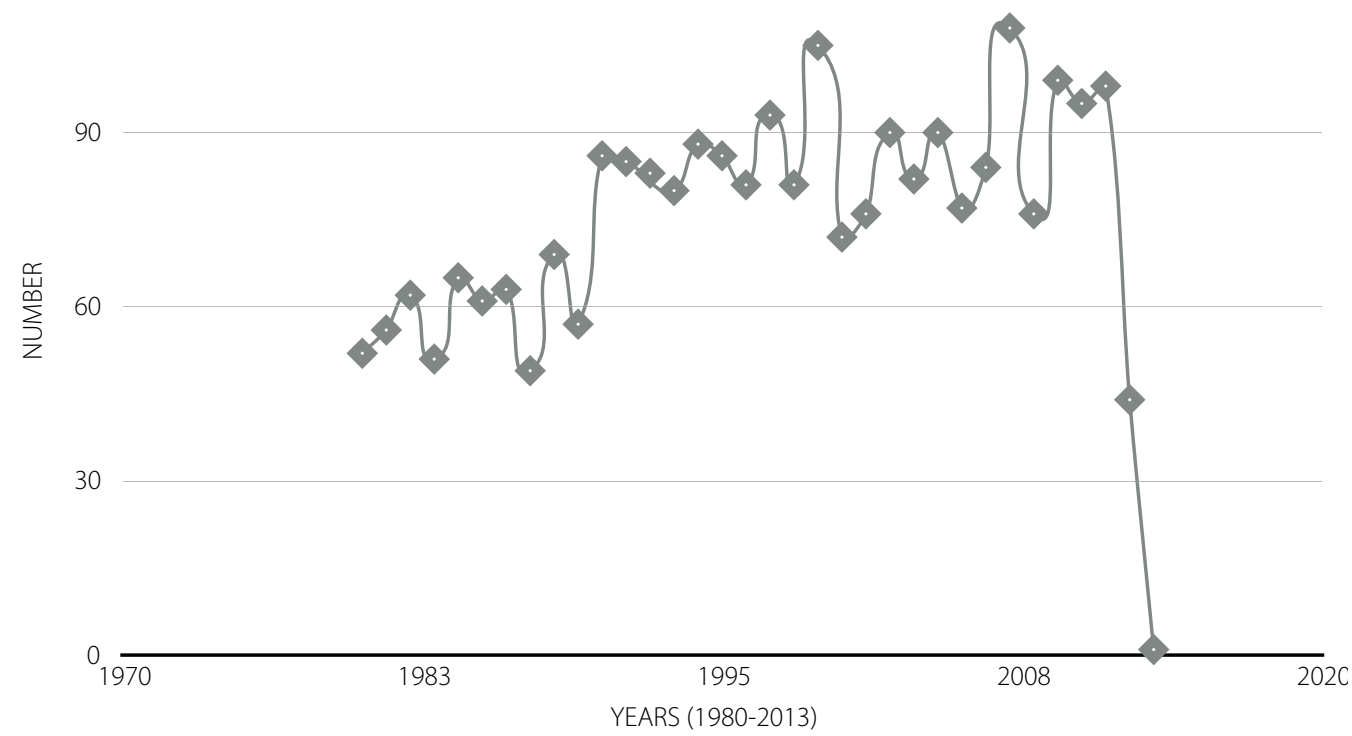

Source: Author's Compilation Based on the Data Obtained in the Search Equations of Table 1.

This shows the growing interest on this topic within the international scientific community. It is worth mentioning that the downfall shown in Figure 1 is due to the level of production for the first months of the current year (2013). This year's projection will be adapted to the regular behavior of research growth regarding this topic.

Likewise, the selection criteria were revised and we found that the criterion most frequently met was the topic of Organizational Design.

Table 3. Number of Articles that Meet a Certain Number of Criteria

\begin{tabular}{|c|c|c|}
\hline Criteria Met by Article & Number of Articles & Percentage Distribution \\
\hline 1 & 100 & $61 \%$ \\
\hline 2 & 48 & $29 \%$ \\
\hline 3 & 2 & $1 \%$ \\
\hline 4 & 13 & $8 \%$ \\
\hline Total & $\mathbf{1 6 3}$ & $\mathbf{1 0 0} \%$ \\
\hline
\end{tabular}

Source: Author's Compilation Based on the Articles Found by the Search Equation Applied to the Consulted Databases. 
The development of new methods that can generate structures to transfer research results obtained in companies or higher education institutions is really important and interesting. We present an analysis of this process from the construction of graphics and punctual analysis that will account for the current status of this topic. This revision will be divided in three parts: (1) Information about the production of articles within the last three decades. This analysis is complemented by the Production Distribution Degree, the Co-writing Degree, and the Production Degree per Country; (2) The second analysis comprehends the degree of criteria met by the articles with respect to the central axis of the topic analyzed; (3) Approach Degree and methodology used for each article.

\section{Information Regarding the Production of Articles within the Last Three Decades; Analysis Complemented by the Production Distribution Degree,}

\section{the Co-writing Degree, and the Production Degree per Country}

Throughout history, the need to generate economies able to endure global changes has been essential to foster the development of technologies able to place societies at the forefront in order to generate more resources and, therefore, better stability to their inhabitants. Likewise, the need to create support networks arises in order to generate a solidary information exchange between the generator of ideas and the entity that applies and benefits from them. Based on the search for an optimal organizational design, people have investigated different ways and methods to apply an efficient system to transfer the results of a research regarding an organizational design. This has led us to present the production degree of papers on this topic through an analysis of the filtered articles that met the requirements mentioned in the introduction.

Figure 4. Number of Articles per Year

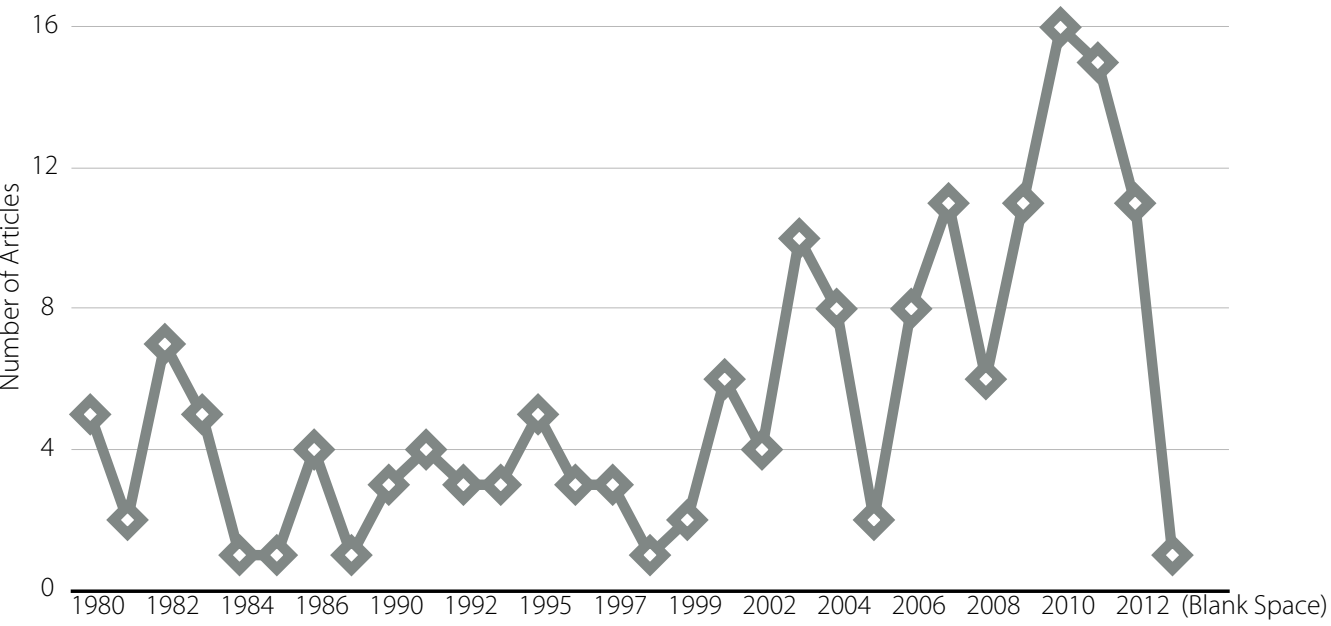

Source: Author's Compilation 


\section{Production Distribution Degree, Complementary Analysis}

Because this research is based on a bibliometric analysis that follows up the status of the research within a time frame of 33 years, we analyzed the distribution degree of the production per Author and the Co-writing Degree that exists in each research document.

Table 4. Production Distribution Degree (Main Author)

\begin{tabular}{|c|c|}
\hline $\begin{array}{c}\text { Number of Articles They } \\
\text { Co-write }\end{array}$ & Number of Authors \\
\hline 1 & 145 \\
\hline 2 & 7 \\
\hline 3 & 1 \\
\hline
\end{tabular}

Source: Author's Compilation

Figure 5. Number of Main Authors with Respect to the Number of Articles They Co-write

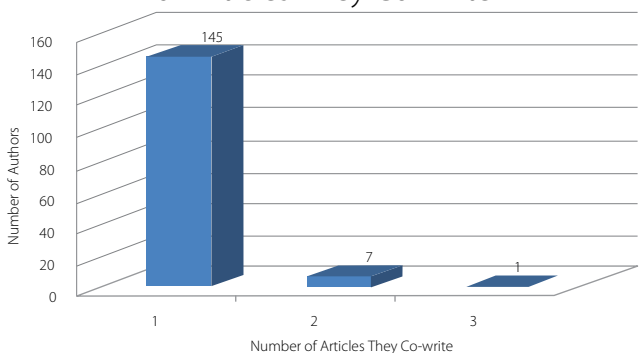

Source: Author's Compilation

Table 5. Co-writing Degree

\begin{tabular}{|c|c|c|}
\hline $\begin{array}{c}\text { Number of } \\
\text { Authors }\end{array}$ & $\begin{array}{c}\text { Number of } \\
\text { Articles }\end{array}$ & $\begin{array}{c}\text { Percentage } \\
\text { Distribution }\end{array}$ \\
\hline 1 & 60 & $37 \%$ \\
\hline 2 & 58 & $36 \%$ \\
\hline 3 & 28 & $17 \%$ \\
\hline 4 & 13 & $8 \%$ \\
\hline
\end{tabular}

\begin{tabular}{|c|c|c|}
\hline $\begin{array}{c}\text { Number of } \\
\text { Authors }\end{array}$ & $\begin{array}{c}\text { Number of } \\
\text { Articles }\end{array}$ & $\begin{array}{c}\text { Percentage } \\
\text { Distribution }\end{array}$ \\
\hline 5 & 1 & $1 \%$ \\
\hline 6 & 1 & $1 \%$ \\
\hline 7 & 0 & $0 \%$ \\
\hline 8 & 1 & $1 \%$ \\
\hline Total & $\mathbf{1 6 2}$ & $\mathbf{1 0 0} \%$ \\
\hline
\end{tabular}

Source: Author's Compilation

Figure 6. Number of Co-writers Regarding Number of Articles They Co-write

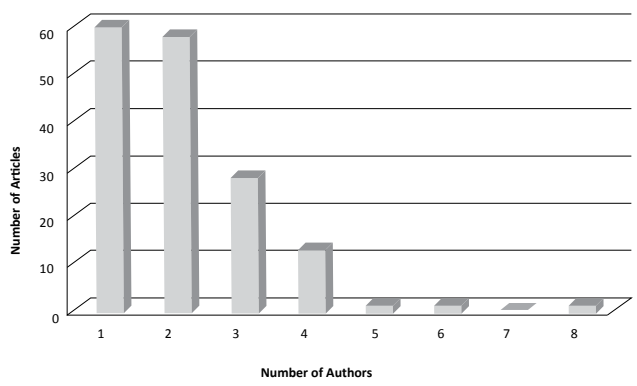

Source: Author's Compilation

Figure 7. Co-writing Percentage Distribution

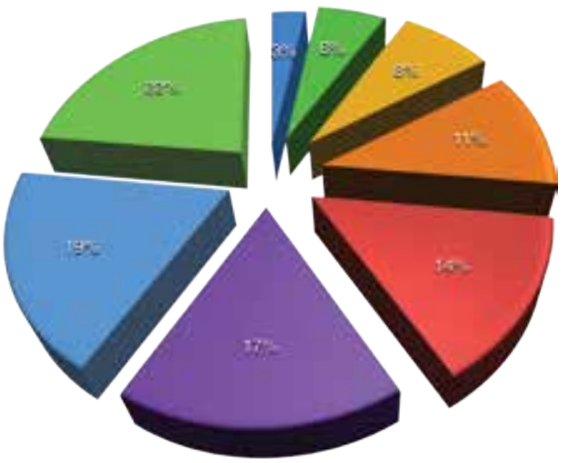

Source: Author's Compilation 


\section{Production Degree per Country}

After analyzing the production degree, with respect to its main authors and the co-writing degree, it is natural to think of an analysis based on the degree of global production. This analysis was carried out focused on the place where the research related to the central topic of this paper was developed. Below, you can find the figure that indicates the production degree per country:

Figure 8. Production Degree per Country

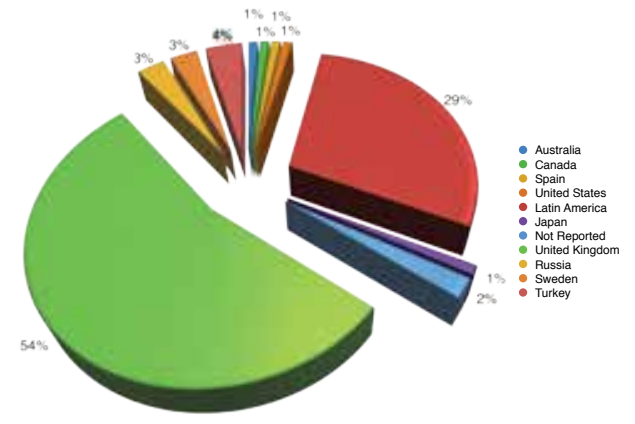

Source: Author's Compilation

\section{Degree of Approach and Methodology Used for Each Article}

In order to measure the degree of approach, we classified the articles as quantitative, qualitative, and mixed -a hybrid between the quantitative and the qualitative approach. These classifications were made after reading the abstract of each filtered article and the following table was produced:
Table 6. Number of Articles

Regarding Type of Approach

\begin{tabular}{|c|c|c|}
\hline Approach & $\begin{array}{c}\text { Number of } \\
\text { Articles }\end{array}$ & $\begin{array}{c}\text { Percentage } \\
\text { Distribution }\end{array}$ \\
\hline Quantitative & 34 & $21 \%$ \\
\hline Qualitative & 114 & $70 \%$ \\
\hline Mixed & 14 & $9 \%$ \\
\hline Total & $\mathbf{1 6 2}$ & $\mathbf{1 0 0} \%$ \\
\hline
\end{tabular}

Source: Author's Compilation

As you can see, the approach of an organizational design (OD) research and of the research results transfer structures (OTRI) is represented qualitatively by $70 \%$. This can be seen in the following figure:

Figure 9. Number of Articles

Regarding Type of Approach

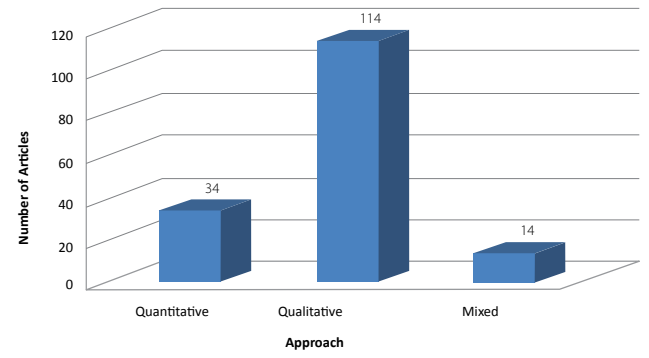

Source: Author's Compilation

\section{Methods Used}

It was necessary to delve into the methodology used according to the type of approach due to the approach degree. This means, if it was a Qualitative Approach, it was possible to use surveys and Focus Group; however, if it was a Quantitative Approach, it was necessary to use surveys, econometric analysis, and data mining. Sometimes, several articles presented a combination of methodologies when using a hybrid approach. 
Here, we present the number of articles per type of approach that had a specific type of methodology:

Table 7. Number of Articles that Applied

Any Type of Methodology

According to the Approach

\begin{tabular}{|c|c|c|c|}
\hline Approach & $\begin{array}{c}\text { Number of } \\
\text { Articles }\end{array}$ & $\begin{array}{c}\text { Percentage } \\
\text { Distribution }\end{array}$ & Mixed \\
\hline Interviews & 18 & 1 & 12 \\
\hline Focus Group & 16 & 20 & 12 \\
\hline Econometrics & 0 & 14 & 5 \\
\hline Surveys & 0 & 19 & 12 \\
\hline Data-Mining & 10 & 31 & 12 \\
\hline Total & 44 & 85 & 53 \\
\hline
\end{tabular}

Source: Author's Compilation

Table 8. Authors per Type of Methodology Applied

\begin{tabular}{|c|c|}
\hline Methodology & Authors \\
\hline Interviews & $\begin{array}{l}\text { (Anspach, 1991; Cocks, 1980; Dean Jr. \& Snell, 1991; Deshpande \& Zal- } \\
\text { tman, 1982; Deshpande, 1982; Dill, 1995; Dougherty, 1992; Glick, Hu- } \\
\text { ber, Miller, Doty, \& Sutcliffe, 1990; Gurkov \& Settles, 2011; Hannan, } \\
\text { Pólos, \& Carroll, 2003; Hax \& Majluf, 1981; Heimann, 1993; Huber \& } \\
\text { McDaniel, 1986; Kaiser \& Bostrom, 1982; Kozma, 1985; Krackhardt \& } \\
\text { Stern, 1988; Lane, 1983; Leidner \& Elam, 1995; Long, 1980; Perrow, } \\
\text { 1983; Rivkin \& Siggelkow, 2003; Rowland \& Parry, 2009; Sloper, 1982; } \\
\text { Sun \& Scott, 2005; Ashoorkhani, Gholami, \& Majdzadeh, 2011; Bart- } \\
\text { lett, 2009; Boardman \& Ponomariov, 2011; Dee, Henkin, \& Single- } \\
\text { ton, 2006; Klein, 1996; Visscher \& Visscher-Voerman, 2010; Werner- } \\
\text { felt, 2004) }\end{array}$ \\
\hline Focus Group & $\begin{array}{l}\text { (Andriopoulos \& Lewis, 2009; Anspach, 1991; Bozionelos, 2008; Burns } \\
\text { \& Wholey, 1993; Caldwell, 1991; Carley \& Lin, 1997; Cocks, 1980; Coo- } \\
\text { per \& Zmud, 1990; Deshpande \& Zaltman, 1982; Deshpande, 1982; } \\
\text { Dill, 1995; Dougherty, 1992; Fang, Lee, \& Schilling, 2010; Glick et al., } \\
\text { 1990; Hax \& Majluf, 1981; Heimann, 1993; Ivarsson \& Gorschek, 2009; } \\
\text { Jin, Levitt, Christiansen, \& Kunz, 1995; Kaiser \& Bostrom, 1982; Kozma, } \\
\text { 1985; Krackhardt \& Stern, 1988; Kusunoki, Nonaka, \& Nagata, 1998; } \\
\text { Lane, 1983; Leidner \& Elam, 1995; Lloria, 2007; Long, 1980; Novo, Mur- } \\
\text { ga-Menoyo, \& Bautista-Cerro, 2010; Perrow, 1983; Silva et al., 2011; Ri- } \\
\text { vkin \& Siggelkow, 2003; Rowland \& Parry, 2009; Sloper, 1982; Sun \& } \\
\text { Scott, 2005; Tillquist, King, \& Woo, 2002; Allen, 2003; Ashoorkhani et } \\
\text { al., 2011; Åström, 2008; Bartlett, 2009; Boardman \& Ponomariov, 2011; } \\
\text { Boardman \& Corley, 2008; Dee et al., 2006; Kaiser \& Buxmann, 2012; } \\
\text { Klein, 1996; Pal \& Torstensson, 2011; Visscher \& Visscher-Voerman, } \\
\text { 2010; Whitworth, Haining, \& Stringer, 2012; Ylldı, 2012) }\end{array}$ \\
\hline
\end{tabular}




\begin{tabular}{|c|c|}
\hline Methodology & Authors \\
\hline Econometrics & $\begin{array}{l}\text { (Novo et al., 2010; Pentland, 2003; Roberts \& Greenwood, 1997"type" } \\
\text { : "article-journal", "volume" : "22" \}, "uris" : [ "http://www.mendeley. } \\
\text { com/documents/?uuid=1b293e2b-f9c5-4a11-b3ed-5a766ca11449" } \\
\text { ] \} ], "mendeley" : \{ "manualFormatting" : "Roberts \& Greenwood, } \\
\text { 1997", "previouslyFormattedCitation" : "(Roberts \& Greenwood, 1997; } \\
\text { Royston \& Wright, 1997; Sloper, 1982; Te'eni, 2001; Haas, 2006; Kaiser } \\
\text { \& Buxmann, 2012; Pal \& Torstensson, 2011) }\end{array}$ \\
\hline Surveys & $\begin{array}{l}\text { (Anspach, 1991; Burns \& Wholey, 1993; Dill, 1995; Ethiraj \& Levinthal, } \\
\text { 2004; Fang et al., 2010; Kaiser \& Bostrom, 1982; Krackhardt \& Stern, } \\
\text { 1988; Levitt et al., 1999; Lewin \& Minton, 1986; Lloria, 2007; Lovejoy } \\
\text { \& Sinha, 2010; Andriopoulos \& Lewis, 2009; Novo et al., 2010; Bozio- } \\
\text { nelos, 2008; Caldwell, 1991; Carley \& Lin, 1997; Cocks, 1980; Cooper \& } \\
\text { Zmud, 1990; Davis, Strand, Alexander, \& Hussain, 1982; Deshpande \& } \\
\text { Zaltman, 1982; Dill, 1995; Gurkov \& Settles, 2011; Hannan et al., 2003; } \\
\text { Jin et al.., 1995; Kaiser \& Bostrom, 1982; Long, 1980; Silva et al., 2011; } \\
\text { Rowland \& Parry, 2009; Sloper, 1982; Sun \& Scott, 2005; Te'eni, 2001; } \\
\text { Tillquist et al., 2002; Ungson, Braunstein, \& Hall, 1981; Allen, 2003; } \\
\text { Boardman \& Corley, 2008; Haas, 2006; Ylldız, 2012) }\end{array}$ \\
\hline Data-Mining & $\begin{array}{l}\text { (Andriopoulos \& Lewis, 2009; Anspach, 1991; Boudreau, 2004; Bozio- } \\
\text { nelos, 2008; Burns \& Wholey, 1993; Caldwell, 1991; Carley \& Lin, 1997; } \\
\text { Cocks, 1980; Cooper \& Zmud, 1990; Daft \& Lengel, 1986; Dahlgren } \\
\text { \& Cokus, 2007; Davis et al., 1982; Dean Jr. \& Snell, 1991; DeSanctis, } \\
\text { Glass, \& Ensing, 2002; Deshpande \& Zaltman, 1982; Dill, 1995; Ethiraj } \\
\text { \& Levinthal, 2004; Fang et al., 2010; Heimann, 1993; Hevner, March, } \\
\text { Park, \& Ram, 2004; Huber \& McDaniel, 1986; Huber, 1990; Jin et al., } \\
\text { 1995; Kaiser \& Bostrom, 1982; Kozma, 1985; Krackhardt \& Stern, 1988; } \\
\text { Kusunoki et al., 1998; Lane, 1983; Lee, Barua, \& Whinston, 1991; Le- } \\
\text { vitt et al., 1999; Lewin \& Minton, 1986; Lloria, 2007, Long, 1980; Love- } \\
\text { joy \& Sinha, 2010; Novo et al., 2010; Pentland, 2003; Silva et al., 2011; } \\
\text { Orlikowski \& Barley, 2001; Roberts \& Greenwood, 1997"type" : "arti- } \\
\text { cle-journal", "volume" : "22" \}, "uris" : [ "http://www.mendeley.com/ } \\
\text { documents/?uuid=1b293e2b-f9c5-4a11-b3ed-5a766ca11449" ] \} ], } \\
\text { "mendeley": : "manualFormatting" : "Roberts \& Greenwood, 1997", } \\
\text { "previouslyFormattedCitation" : "(Roberts \& Greenwood, 1997; Slo- } \\
\text { per, 1982; Sun \& Scott, 2005; Te'eni, 2001; Tillquist et al., 2002; Trauth } \\
\text { \& Cole, 1992; Ungson et al., 1981; Alavi \& Leidner, 2001; Allen, 2003; } \\
\text { Asström, 2008; Haas, 2006; Kaiser \& Buxmann, 2012; Klein, 1996; Pal \& } \\
\text { Torstensson, 2011; Whitworth et al., 2012) }\end{array}$ \\
\hline
\end{tabular}

This table shows that the most frequently used methodology in the qualitative approach is surveys, while the most applied in the quantitative approach is data-mining. This can be seen in the following figure: 
Figure 10. Number of Articles that Applied Any Type of Methodology

According to the Approach

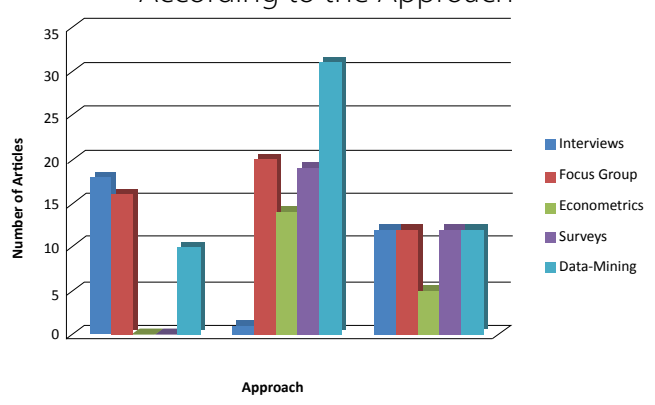

Source: Author's Compilation

\section{Discussion}

It is important to highlight that the literature on theoretical terms has a gap regarding the aforementioned methodology. Latin American reality -especially in Colombia- does not compare to the contexts that have been successful in the generation of transferable research results, susceptible to generate economic development. Also, many of public policy makers are trying to emulate them (Inventta, 2011).

According to Mintzberg (2001), every human activity that requires to be organized originates two requirements: division of labor and coordination of tasks (page 6). This way, organizational design is the result of the construction or of the change of structure within an organization. All this oriented to the achievement of its goals.

Mintzberg proposes these designs as OD dimensions: positions, superstructure, design of lateral linkages, and design of a decision-making system. The parameters for the design of positions are mediated by two variables: job specialization and behavior formalization, but the parameters for superstructure are degree of unit grouping and of unit size. This theory cannot be applied to the R\&D environment in Higher Education Institutions, as stated in the integrated vision of the new concepts of organizational design, DeSanctis, Glass, \& Ensing, (2002). They describe three ways to organize work for $\mathrm{R} \& \mathrm{D}$ activities at business level: Decentralized, Integrated, and Network.

The Decentralized design is characterized by having one R\&D unit for each business unit saving the idea of having central control schemes for that function. Integrated DO has a centralized R\&D area and allows the functioning of projects within business units without losing the control of the system or its information (DeSanctis et al., 2002, p. 62).

Network organization and the theories of Anand \& Daft, (2007) regarding the third stage of OD are on the same page. They argue that it is necessary to go beyond and ask for the collaboration of others in order to achieve a common objective. The paradigm here is to research in alliance with the government and research universities.

The approach of the aforementioned authors allows having an OD overview, more specifically regarding $R \& D$ in productive sectors. Nevertheless, Bahrami, (1992) concludes, as well as Red de DeSanctis et al., (2002), while studying some cases in Silicon Valley, that it is important to leave behind monolithic models for the organization of work in order to increase flexibility within innovation and development.

Bahrami states that the emergence of flexible organizations within the context of innovation and technological contexts faces dialectic tensions between control 
and autonomy by enabling individual creativity and avoiding chaos. In addition, and from its empirical validation, the author finds essential differences between the organizational attributes of the traditional and the emerging models. These are summarized on the table below:

Table 3. Comparison of Organizational Attributes (From the Traditional Model to Flexibility)

\begin{tabular}{|c|c|}
\hline Traditional Model & Emerging Model \\
\hline Only Center & ultiple Centers \\
\hline Autonomous & Panel of Experts \\
\hline Independent Activities & Interdependent Units \\
\hline Vertical Integration & Multiple Alliances \\
\hline Uniform Structure & Diverse Structures \\
\hline Provincial Thinking & Cosmopolitan Thinking \\
\hline Emphasis on Efficiency & Emphasis on Flexibility \\
\hline
\end{tabular}

Source: Author's Compilation Based on the Data Obtained from Bahrami, (1992)

In contrast, this research reflects in Colombia what Bahrami, (1992) stated while studying cases in Silicon Valley regarding the importance of leaving monolithic models behind when organizing labor in order to increase flexibility within innovation and development. The author also indicates that when a flexible organization appears in the context of innovation and of technological development, it faces reasoning tensions between control and autonomy so it is necessary to give space to creativity without reaching chaos.

\section{References}

Alavi, M., \& Leidner, D. E. (2001). Review: Knowledge Management and Knowledge Management Systems: Conceptual Foundations and Research Issues. MIS Quarterly, 25, 107-136. Retrieved from http://www.jstor.org/discover $/ 10.2307 / 3250961$ ? uid $=2 \&$ uid $=4 \&$ sid $=21102752523497$

Allen, D. K. (2003). Organisational Climate and Strategic Change in Higher Education: Organisational Insecurity. Higher Education, 46, 61-92. Retrieved from http://link.springer.com/article/10.1023 \%2FA\%3A1024445024385

Anand, N., \& Daft, R. (2007). What is the Right Organization Design? Organizational Dynamics, 36, 329-344.

Andriopoulos, C., \& Lewis, M. W. (2009). Exploitation-exploration Tensions and Organizational Ambidexterity: Managing Paradoxes of Innovation. Organization Science, 20, 696-717. Retrieved from http://dx.doi.org/10.1287/ orsc. 1080.0406

Anspach, R. R. (1991). Everyday Methods for Assessing Organizational Effectiveness. Social Problems, 38, 1-19.

Arocena, R., \& Sutz, J. (2001). Changing Knowledge Production and Latin American Universities. Research Policy, 30, 1221-1234.

Arvanitis, S., Kubli, U., \& Woerter, M. (2008). University-industry Knowledge and Technology Transfer in Switzerland: What University Scientists Think about Co-operation with Private Enterprises. Research Policy, 37, 1865-1883.

Ashoorkhani, M., Gholami, J., \& Majdzadeh, R. (2011). Do We Transfer Health Research Results to People? Int J Prev Med, 2, 103-104. 
Åström, F. (2008). Formalizing a Discipline: The Institutionalization of Library and Information Science Research in the Nordic Countries. Journal of Documentation, 64(5), 721-737. Retrieved from http://www.scopus.com/inward/record. url?eid=2-s2.0-52649161829\&partnerI $\mathrm{D}=40 \& \mathrm{md} 5=\mathrm{fa} 85 \mathrm{~b} 6 \mathrm{e} 8313 \mathrm{da} 2 \mathrm{~b} 42848$ d91cbc7055fd

Bahrami, H. (1992). The Emerging Flexible Organization: Perspectives from Silicon Valley. California Management Review, 33-52.

Bartlett, D. (2009). Embedding Corporate Responsibility: The Development of a Transformational Model of Organizational Innovation. Corporate Governance, 9(4), 409-420. Retrieved from http://www.scopus.com/inward/record. url?eid=2-s2.0-70349635977\&partnerI $\mathrm{D}=40 \& \mathrm{md} 5=855 \mathrm{e} 5 \mathrm{adc} 78 \mathrm{bd} 3 \mathrm{~b} 25 \mathrm{e} 689$ e20f7b09a10c

Boardman, C., \& Ponomariov, B. (2011). A Preliminary Assessment of the Potential for "Team Science" in DOE Energy Innovation Hubs and Energy Frontier Research Centers. Energy Policy, 39(6), 3033-3035. Retrieved from http://www. scopus.com/inward/record.url?eid=2s2.0-79955902149\&partnerID $=40 \& \mathrm{~m}$ d5 $=950000$ e2793a0382ee1224730f58 $9 \mathrm{~d} 7 \mathrm{e}$

Boardman, P. C., \& Corley, E. A. (2008). University Research Centers and the Composition of Research Collaborations. Research Policy, 37(5), 900913. Retrieved from http://www. scopus.com/inward/record.url?eid=2s2.0-43449106182\&partnerID $=40 \& \mathrm{md}$ $5=$ d0e919bd1980aa2dab445ef99ff3be89

Boudreau, J. W. (2004). Organizational Behavior, Strategy, Performance, and Design in "Management Science". Management Science, 50, 1463-1476. Retrieved from http:// www.jstor.org/discover/10.2307/3004795 8?uid $=2 \&$ uid $=4 \&$ sid $=21102752325907$

Bozionelos, N. (2008). Intra-organizational Network Resources: How They Relate to Career Success and Organizational Commitment. Personnel Review, 37(3), 249-263. Retrieved from http://www. scopus.com/inward/record.url?eid=2s2.0-42149119615\&partnerID $=40 \&$ $\mathrm{md} 5=\mathrm{c} 2728 \mathrm{c} 1 \mathrm{c} 36 \mathrm{ddaca} 9 \mathrm{bd} 10 \mathrm{~b} 87863$ $8 \mathrm{f} 94 \mathrm{~d} 9$

Bugliarello, G. (1996). Urban Knowledge Parks and Economic and Social Development Strategies. Journal of Urban Planning and Development, 122, 33-45.

Burns, L. R., \& Wholey, D. R. (1993). Adoption and Abandonment of Matrix Management Programs: Effects of Organizational Characteristics and Inter-organizational Networks. Academy of Management Journal, 36(1), 106-138. Retrieved from http://www. scopus.com/inward/record.url?eid=2s2.0-0027549942\&partnerID $=40 \& \mathrm{md}$ $5=68046 \mathrm{a} 0255 \mathrm{c} 8240 \mathrm{ae} 8 \mathrm{f} 8 \mathrm{f} 1399 \mathrm{ba} 073 \mathrm{c} 9$

Caldwell, B. S. (1991). New View of Quantifying Organizational Climate through the Work Environment Scale. Proceedings of the Human Factors Society (Vol. 2, pp. 930-933). Retrieved from http://www. scopus.com/inward/record.url?eid=2s2.0-0025748313\&partnerID $=40 \& \mathrm{md} 5$ $=41630003 \mathrm{c} 51 \mathrm{~b} 4 \mathrm{e} 2 \mathrm{~d} 87 \mathrm{ccad} 1 \mathrm{~b} 7 \mathrm{ac} 2 \mathrm{ebcd}$

Carley, K. M., \& Lin, Z. (1997). A Theoretical Study of Organizational Performance under Information Distortion. Management Science, 43, 976-997. Retrieved from http://mansci.journal.informs.org/ content/43/7/976.abstract

Cocks, P. (1980). Rethinking the Organizational Weapon: The Soviet System in a Systems Age. World Politics, 32, 228-257. Coenen, L., Moodysson, J., Ryan, C., Asheim, B., \& Phillips, P. (2006). Comparing a 
Pharmaceutical and an Agro-food Bioregion: On the Importance of Knowledge Bases for Socio-spatial Patterns of Innovation. Industry \& Innovation, Taylor and Francis Journals, 13, 393-414.

Cooke, P. (2002). Knowledge Economies: Clusters, Learning and Cooperative Advantage. London: Routledge Studies in International Business and the World Economy.

Cooper, R. B., \& Zmud, R. W. (1990). Information Technology Implementation Research: A Technological Diffusion Approach. Management Science, 36, 123139. Retrieved from http://www.jstor.org/ discover $/ 10.2307 / 2661451$ ? uid $=2 \&$ uid $=4$ \&sid $=21102752129067$

Cummings, S., Rosentraub, M., Domahidy, M., \& Coffin, S. (2005). University Involvement in Downtown Revitalization: Managing Political and Financial Risks. The University as Urban Developer: Case Studies and Analysis. M.E. Sharpe, Inc.

Daft, R. L., \& Lengel, R. H. (1986). Organizational Information Requirements, Media Richness and Structural Design. Management Science, 32, 554-571. Retrieved from http://www.jstor.org/ discover/10.2307/2631846?uid=2\&uid $=4 \&$ sid $=21102752325907$

Dahlgren, J. W., \& Cokus, M. S. (2007). Real Options and Flexibility in Organizational Design. Proceedings of the 1st Annual 2007 IEEE Systems Conference (pp. 78-84). Retrieved from http://www. scopus.com/inward/record.url?eid=2s2.0-34748926352\& partnerID $=40 \&$ $\mathrm{md} 5=$ cec $6208070 \mathrm{ef} 3035 \mathrm{c} 40 \mathrm{c} 5 \mathrm{f} 9843 \mathrm{e}$ $4249 \mathrm{~d}$

Davis, R. H., Strand, R., Alexander, L. T., \& Hussain, M. N. (1982). The Impact of Organizational and Innovator Variables on Instructional Innovation in Higher Education. The Journal of Higher Education, 53,
568. Retrieved from http://www.jstor.org/ discover $/ 10.2307 / 1981854$ ? uid $=2 \&$ uid $=4$ \&sid $=21102752325907$

Dean Jr., J. W., \& Snell, S. A. (1991). Integrated Manufacturing and Job Design: Moderating Effects of Organizational Inertia. Academy of Management Journal, 34, 776-804.

Dee, J. R., Henkin, A. B., \& Singleton, C. A. (2006). Organizational Commitment of Teachers in Urban Schools: Examining the Effects of Team Structures. Urban Education, 41(6), 603-627. Retrieved from http://www.scopus.com/inward/ record.url?eid=2-s2.0-33749841655\&par tnerID $=40 \& \mathrm{md} 5=\mathrm{c} 8 \mathrm{fc} 2 \mathrm{aa} 338 \mathrm{fe} 21 \mathrm{e} 433$ fa63e7f7be2cf1

DeSanctis, G., Glass, J. T., \& Ensing, I. M. (2002). Organizational Designs for R\&D. Academy of Management Executive, 16(3), 55-66. Retrieved from http://www.scopus.com/inward/record. url?eid=2-s2.0-14244271958\&partner $\mathrm{ID}=40 \& \mathrm{md} 5=\mathrm{fc} 1283 \mathrm{~b} 6760 \mathrm{ea} 31 \mathrm{ba} 466$ 0176df399d2f

Deshpande, R. (1982). The Organizational Context of Market Research Use. Journal of Marketing, 46, 91-101.

Deshpande, R., \& Zaltman, G. (1982). Factors Affecting the Use of Market Research Information: A Path Analysis. Journal of Marketing Research, 19, 14-31. Dill, D. D. (1995). University-industry Entrepreneurship: The Organization and Management of American University Technology Transfer Units. Higher Education, 29, 369-384.

Dougherty, D. (1992). A Practice-centered Model of Organizational Renewal through Product Innovation. Strategic Management Journal, 13, 77-92.

Ethiraj, S. K., \& Levinthal, D. (2004). Bounded Rationality and the Search for Organizational Architecture: An 
Evolutionary Perspective on the Design of Organizations and Their Evolvability. Administrative Science Quarterly, 49, 404-437. Retrieved from http://www. jstor.org/discover/10.2307/4131441?uid= 2\&uid $=4 \&$ sid $=21102752325907$

Fang, C., Lee, J., \& Schilling, M. A. (2010). Balancing Exploration and Exploitation Through Structural Design: The Isolation of Subgroups and Organizational Learning. Organization Science, 21, 625642. Retrieved from http://orgsci.journal.informs.org/content/21/3/625.full. pdf

Fleet, G. H. (1993). The Microorganisms of Winemaking-isolation Enumeration and Identification. Wine Microbiology and Biotechnology (pp. 1-27). Switzerland: Harwood Academic Publishers, Chur.

Glick, W. H., Huber, G. P., Miller, C. C., Doty, D. H., \& Sutcliffe, K. M. (1990). Studying Changes in Organizational Design and Effectiveness: Retrospective Event Histories and Periodic Assessments. Organization Science, 1, 293-312.

Gurkov, I., \& Settles, A. (2011). Managing Organizational Stretch to Overcome the Uncertainty of the Great Recession of 2008. International Journal of Organizational Analysis, 19(4), 317330. Retrieved from http://www.scopus.com/inward/record.url?eid=2-s2.080054018472\&partnerID $=40 \& \mathrm{md} 5=$ 73a49c4ef482ccaf2a20136bbb54aab9

Haas, M. R. (2006). Knowledge Gathering, Team Capabilities, and Project Performance in Challenging Work Environments. Management Science, 52(8), 1170-1184. Retrieved from http://www. scopus.com/inward/record.url?eid=2s2.0-33744797432\&partnerID $=40 \& \mathrm{md}$ 5=700b16a09e8dcecf1a3b5d838d732067
Hannan, M. T., Pólos, L., \& Carroll, G. R. (2003). Cascading Organizational Change. Organization Science, 14, 463482.

Hax, A. C., \& Majluf, N. S. (1981). Organizational Design: A Survey and an Approach. Operations Research, 29, 417447.

Heimann, C. F. L. (1993). Understanding the Challenger Disaster: Organizational Structure and the Design of Reliable Systems. American Political Science Review, 87, 421-435.

Hevner, A. R., March, S. T., Park, J., \& Ram, S. (2004). Design Science in Information Systems Research. MIS Quarterly, 28, 75-105.

Huber, G. P. (1990). A Theory of the Effects of Advanced Information Technologies on Organizational Design, Intelligence, and Decision Making. The Academy of Management Review, 15, 47-71. Retrieved from http://www.jstor.org/dis cover $/ 10.2307 / 258105$ ?uid $=2 \&$ uid $=4 \&$ sid $=21102752523497$

Huber, G. P., \& McDaniel, R. R. (1986). The Decision-Making Paradigm of Organizational Design. Management Science, 32, 572-589.

Inventta. (2011). Análisis de Capacidades: Alianza Universidad-Empresa-Estado (Capacity Analysis: University-BusinessState Alliance.) Bogotá D.C.: Power Point Presentation, Inventta Colombia. Ivarsson, M., \& Gorschek, T. (2009). Technology Transfer Decision Support in Requirements Engineering Research: A Systematic Review of REj. Requirements Engineering Journal, 14, 155-175.

Jin, Y., Levitt, R. E., Christiansen, T. R., \& Kunz, J. C. (1995). Virtual Design Team: Modeling Organizational Behavior of Concurrent Design Teams. Artificial Intelligence for Engineering Design, 
Analysis and Manufacturing: AIEDAM, 9(2), 145-158. Retrieved from http:// www.scopus.com/inward/record. url?eid=2-s2.0-0029289177\&partnerI $\mathrm{D}=40 \& \mathrm{md} 5=\mathrm{cf} 8 \mathrm{~b} 9317 \mathrm{~d} 25 \mathrm{fae} 1273336$ $437 \mathrm{ec} 023 \mathrm{~b} 89$

Kaiser, J., \& Buxmann, P. (2012). Organizational Design of IT Supplier Relationship Management: A Multiple Case Study of Five Client Companies. Journal of Information Technology, 27(1), 57-73. Retrieved from http://www.scopus.com/inward/record.url?eid=2-s2.084856593902\&partnerID $=40 \& \mathrm{md} 5=$ 4bdc93a0691a51e477f6fa927f1d5993

Kaiser, K. M., \& Bostrom, R. P. (1982). Personality Characteristics of MIS Project Teams: an Empirical Study and Action-research Design. MIS Quarterly, 6, 43-60.

Klein, S. (1996). The Configuration of Inter-organizational Relations. European Journal of Information Systems, 5(2), 92-102. Retrieved from http://www.scopus.com/inward/record.url?eid=2-s2.021344472090\&partnerID $=40 \& \mathrm{md} 5=$ 9467139bc3c71b3170206fa37fd44aae

Kozma, R. B. (1985). A Grounded Theory of Instructional Innovation in Higher Education. Journal of Higher Education, 56, 300.

Krackhardt, D., \& Stern, R. N. (1988). Informal Networks and Organizational Crises: An Experimental Simulation. Social Psychology Quarterly, 51, 123-140.

Kusunoki, K., Nonaka, I., \& Nagata, A. (1998). Organizational Capabilities in Product Development of Japanese Firms: A Conceptual Framework and Empirical Finding. Organization Science, 9, 699718. Retrieved from http://www.jstor. org $/$ discover $/ 10.2307 / 2640250$ ?uid=2 \&uid $=4 \&$ sid $=21102752207197$
Lane, J.-E. (1983). Higher Education — Public Policy-making and Implementation. Higher Education, 12, 519-565.

Lee, B., Barua, A., \& Whinston, A. B. (1991). Discovery and Representation of Causal Relationships in MIS Research: A Methodological Framework. MIS Quarterly, 21, 109-129. Retrieved from http://www. jstor.org/discover/10.2307/249744?uid= 2\&uid $=4 \&$ sid $=21102752523497$

Leidner, D. E., \& Elam, J. J. (1995). The Impact of Executive Information Systems on Organizational Design, Intelligence, and Decision Making. Organization Science, 6, 645-664.

Levitt, R. E., Thomsen, J., Christiansen, T. R., Kunz, J. C., Jin, Y., \& Nass, C. (1999). Simulating Project Work Processes and Organizations: Toward a Micro-contingency Theory of Organizational Design. Management Science, 45(11), 1479-1495. Retrieved from http://www.scopus.com/inward/record. url?eid=2-s2.0-0033358240\&partnerID $=40 \& \mathrm{md} 5=2 \mathrm{a} 3 \mathrm{a} 3 \mathrm{~d} 2892 \mathrm{bbb} 4 \mathrm{~d} 146 \mathrm{c} 0 \mathrm{~d} 7$ $5884 \mathrm{~d} 75 \mathrm{~b} 08$

Lewin, A. Y., \& Minton, J. W. (1986). Determining Organizational Effectiveness: Another Look and an Agenda for Research. Management Science, 35, 514538.

Lloria, M. B. (2007). Differentiation in Knowledge-creating Organizations. International Journal of Manpower, 28(8), 674-693. Retrieved from http://www. scopus.com/inward/record.url?eid=2s2.0-36448976556\&partnerID $=408 \mathrm{md}$ $5=23$ c773e2be0a 2 b4 3 dff090 caf68ff 1394

Long, R. J. (1980). Job Attitudes and Organizational Performance under Employee Ownership. Academy of Management Journal, 23, 726-737.

Lovejoy, W. S., \& Sinha, A. (2010). Efficient Structures for Innovative Social 
Networks. Management Science, 56, 1127-1145. Retrieved from http://mansci. journal.informs.org/content/56/7/1127. abstract

Luger, M., \& Goldstein, H. (1990). Technology in the Garden. California: Chapel Hill: University of North Carolina Press. Mayer, H. (2007). What Is the Role of the University in Creating a High-Technology Region? Journal of Urban Technology, 14(3), 33-58. doi:10.1080/10630730801924225

Mintzberg, H. (2001). Designing Effective Organizations. Buenos Aires, Argentina: El Ateneo.

Nonaka, I., \& Takeuchi, H. (1999). The Knowledge-creating Company. México D.F.: Oxford University Press.

Nonaka, Ikujiro. (2007). The KnowledgeCreating Company. Harvard Business Review, July-Augus, 162-171.

Novo, M., Murga-Menoyo, M.-Á., \& Bautista-Cerro, M. J. (2010). Educational Advances And Trends For Sustainable Development: A Research Project On Educational Innovation. Journal of Baltic Science Education, 9, 302-314.

Orlikowski, W. J., \& Barley, S. R. (2001). Technology and Institutions: What Can Research on Information Technology and Research on Organizations Learn from Each Other? MIS Quarterly, 25, 145-165. Retrieved from http://www. jstor.org/discover/10.2307/3250927?ui $\mathrm{d}=2 \&$ uid $=4 \&$ sid $=21102752523497$

Ostrander, S. (2004). Democracy, Civic Participation, and the University: A Comparative Study of Civic Engagement on Five Campuses. Nonprofit and Voluntary Sector Quarterly, 33, 74-93.

Pal, R., \& Torstensson, H. (2011). Aligning Critical Success Factors to Organizational Design: A Study of Swedish Textile and Clothing Firms. Business Process Management Journal, 17(3), 403-436.
Retrieved from http://www.scopus. com/inward/record.url?eid=2-s2.079959215913\&partnerID $=40 \& \mathrm{md} 5=$ 39d1d4cle8ec580d1324fe22ec4954d2

Pentland, B. T. (2003). Conceptualizing and Measuring Variety in the Execution of Organizational Work Processes. Management Science, 49, 857-870. Retrieved from http://mansci.journal.informs.org/ content/49/7/857.full.pdf

Perrow, C. (1983). The Organizational Context of Human Factors Engineering. Administrative Science Quarterly, 28, 521-541.

Perry, D., \& Wiewel, W. (2005). The University as Urban Developer: Case Studies and Analysis. M.E. Sharpe.

Rico, R., Fernandez-Rios, M., Rascado, P., \& Sánchez-Manzanares, M. (2004). Teorías Implícitas, Diseño Organizacional y Eficacia (Implicit Theories, Organizational Design and Efficacy.) Revista Interamericana de Psicologia, 38, 121-130.

Rivkin, J. W., \& Siggelkow, N. (2003). Balancing Search and Stability: Interdependencies Among Elements of Organizational Design. Management Science, 49, 290-311.

Roberts, P., \& Greenwood. (1997). Integrating Transaction Cost and Institutional Theories: Towards a Constrained-frequency Framework for Understanding Organizational Design Adoption. The Academy of Management Review, 22, 346-373. Retrieved from http://www. jstor.org/discover/10.2307/259326?uid $=2 \&$ uid $=4 \&$ sid $=21102752325907$

Rodin, J. (2005). The 21st Century Urban University: New Roles for Practice and Research. Journal of the American Planning Association, 17, 237-249.

Rowland, P., \& Parry, K. (2009). Consensual Commitment: A Grounded Theory of the Meso-level Influence of Organizational 
Design on Leadership and Decisionmaking. Leadership Quarterly, 20(4), 535-553. Retrieved from http://www. scopus.com/inward/record.url?eid=2s2.0-67649361336\&partnerID $=40 \& \mathrm{~m}$ d5=b5b5f3c05e608cae39e8736712cfea6d

Royston, P., \& Wright, E. (1997). Age-specific Reference Intervals for Normally Distributed Data. Stata Technical Bulletin, 38, 4-9.

Saxenian, A. (1985). Silicon Valley and Route 128: Regional Prototypes or Historic Exceptions? In Castells, M. Beverly Hills: Sage: High Technology, Space and Society.

Siegel, D., Waldman, D., \& Link, A. (2003). Assessing the Impact of Organizational Practices on the Relative Productivity of University Technology Transfer Offices: An Exploratory Study. Research Policy, 32, 27-48.

Silva, H., Morales, G., León, A., Pacheco, V., Garduño, H., Camacho, A., \& Carpio, C. (2011). Relaciones de transferencia entre habilidades didácticas y científicas: Un análisis experimental (Transfer Relationships between Didactic and Scientific Abilities: An Experimental Analysis.) Suma Psicológica.

Sloper, D. W. (1982). Recent Evaluations in Australian Higher Education: Context and Incidence. Higher Education, 11, 405-440. Retrieved from http://link.springer.com/ article/10.1007\%2FBF00157658

Sun, P. Y.-T., \& Scott, J. L. (2005). An Investigation of Barriers to Knowledge Transfer. Journal of Knowledge Management, 9(2), 75-90. Retrieved from http://www. scopus.com/inward/record.url?eid=2s2.0-18144388352\&partnerID $=40 \& \mathrm{md}$ $5=e 05 b 018 f 8 c b 855237 d 65$ ce3d8cf49ae3

Te'eni, D. (2001). Review: A CognitiveAffective Model of Organizational Communication for Designing It. MIS Quarterly, 25, 251-312. Retrieved from http:// www.jstor.org/discover/10.2307/325093

1 uid=2\&uid=4\&sid=21102752325907 Tiffin, S., \& Kunc, M. (2011). Measuring the Roles Universities Play in Regional Innovation Systems: A Comparative Study between Chilean and Canadian natural Resource-based Regions. Science and Public Policy, 38(1), 55-66. doi:10.3152/ $016502611 X 12849792159317$

Tillquist, J., King, J. L., \& Woo, C. (2002). A Representational Scheme for Analyzing Information Technology and Organizational Dependency. MIS Quarterly, 26, 91-118.

Trauth, E. M., \& Cole, E. (1992). The Organizational Interface: A Method for Supporting End Users of Packaged Software. MIS Quarterly, 16, 35-53. Retrieved from http://www.jstor.org/ discover $/ 10.2307 / 249700$ ? uid=2\&uid= $4 \&$ sid=21102752523497

Ungson, G. R., Braunstein, D. N., \& Hall, P. D. (1981). Managerial Information Processing: A Research Review. Administrative Science Quarterly, 26. Retrieved from http://www.jstor.org/ discover/10.2307/2392604?uid=2\&uid $=4 \&$ sid $=21102752325907$

Vargas-Hernández, J. G. (2006). Los desafíos del diseño organizacional e institucional en un medio ambiente globalizador. Cuadernos de Administración, 35, 81-106. Visscher, K., \& Visscher-Voerman, J. I. A. (2010). Organizational Design Approaches in Management Consulting. Management Decision, 48(5), 713-731. Retrieved from http://www. scopus.com/inward/record.url?eid=2s2.0-77952904207\&partnerID $=40 \&$ md5=ea024ba40ff86e423ab204ee392 $352 \mathrm{e} 0$

Wernerfelt, B. (2004). Organizational Languages. Journal of Economics \& Management Strategy, 13, 461-472. Retrieved 
from http://onlinelibrary.wiley.com/ doi/10.1111/j.1430-9134.2004.00019.x/ abstract

Whitworth, A., Haining, S., \& Stringer, H. (2012). Enhancing Research Capacity across Healthcare and Higher Education Sectors: Development and Evaluation of An Integrated Model. BMC Health Services Research, 12, 287. Retrieved from http://link.springer.com/article/10.1186 \%2F1472-6963-12-287

Wijk, R. Van, Jansen, J. J. P., \& Lyles, M. A. (2008). Inter- and Intra-Organizational Knowledge Transfer: A Meta-Analytic
Review and Assessment of its Antecedents and Consequences, (June).

Yildız, M. L. (2012). The Future of Organizational Design: A Forecasting Study. Metu Studies In Development, 39.

Zahra, S. a., Van de Velde, E., \& Larraneta, B. (2007). Knowledge Conversion Capability and the Performance of Corporate and University Spin-offs. Industrial and Corporate Change, 16(4), 569-608. doi:10.1093/icc/dtm018 